\title{
Analysis of Rice Farming with System of Seeding Direct and Seeding Indirect: A Case Study in Buol Regency Indonesia
}

\author{
Max Nur Alam ${ }^{1}$ \\ ${ }^{1}$ Department of Agriculture Economics, Tadulako University, Indonesia \\ Corresponding author: Max Nur Alam, Department of Agriculture Economics, Faculty of Agriculture, Tadulako \\ University, Indonesia.E-mail: nuralam_max@yahoo.co.id
}

Received: December16, 2014

Accepted: January 6, 2015

Online Published: July 27, 2015

doi:10.5539/mas.v9n8p311

URL: http://dx.doi.org/10.5539/mas.v9n8p311

\begin{abstract}
This research aimed to analyze production and income of rice farming with system of seeding direct and seeding indirect with a variety of input usage. This research was conducted with descriptive and comparative methods that described and compared rice farming with system of seeding direct and seeding indirect. The number of samples that were taken amounted 74 household heads. Samples on seeding direct system were taken by census, amounted 34 household heads. Seeding indirect system was determined by 40 household heads $(20 \%$ of 197 farmers of seeding indirect system), sampling was done by simple random. The result of research showed that rice farming with seeding direct system could save labors when compared with seeding indirect system. The income average of rice farming with seeding direct system were bigger than seeding indirect system. Rice farming with seeding direct system had a prospect to be developed on irrigated rice land with labors that were rare and expensive. However, the application of this system needed to be balanced with the usage of fertilizers, herbicides and reapers, so that labors efficiency could occur.
\end{abstract}

Keywords: Production, Income, Rice, Seeding direct, Seeding indirect

\section{Introduction}

The Increasing of rice production in Indonesia was conducted through intensification and extensification program. Intensification is conducted by improving technology to increase land productivity. Extensification is intended to expand the production area (Soekartawi, 2003).

Areas that are not enable to do farming expansion, then one of business that is able to increase and improve the welfare is by increasing the carrying capacity of land. Technology of seeding direct system and seeding indirect system had been developing to support the carrying capacity of land (Adnyana, 1996). Seeding indirect system generally is conducted by farmers if the labors are many available and cheap. Areas with rare and expensive labors, while the machine price of seeding indirect system is not affordable by farmers, seeding direct system can be an alternative for farmers. The scarcity of labors can cause the cropping time delayed, so the rice production are low, then the seeding direct system is introduced (Rao et al. 2007). The usage objective of seeding direct system is to reduce the usage of labors that are concentrated at the same time such as land cultivation and cropping, as well as to avoid the creation and maintenance of seedbed. Labors efficiency can reduce the cost of labors which are expensive and pursue cropping season simultaneously with cost that are relatively low. Seeding direct system with a optimum management can give the higher crop yields (De Datta and Flinn, 1986; Washio, 1992).

The general objective of this research was to analyze the rice farming with system of seeding direct and seeding indirect. In particular, this research aimed to analyze production and income of rice farming with system of seeding direct and seeding indirect with a variety of input usage.

\section{Research Methods}

This research was conducted with descriptive and comparative methods that described and compared rice farming with system of seeding direct and seeding indirect in Tiloan Sub-regency Buol Regency, Indonesia. Tiloan Sub-regency was an area that had potential in increasing of rice farming production (intensification). There were 197 Household Heads (HH) that applied seeding indirect system and $34 \mathrm{HH}$ applied seeding direct system. This research was conducted on September 2012 to November 2012. 
The number of samples that were taken amounted $74 \mathrm{HH}$. Samples on seeding direct system were taken by census, amounted $34 \mathrm{HH}$. Seeding indirect system was determined by $40 \mathrm{HH}$ (20\% of 197 farmers of seeding indirect system), sampling was done by simple random. Descriptive method and independent t-test statistics were used to analyze production and income of rice farming with system of seeding direct and seeding indirect with a variety of input usage.

\section{Results and Discussion}

\subsection{Input Usage on Seeding Direct System and Seeding Indirect System}

\subsubsection{The Usage of Seeds}

Seeds are one of factors that determined the success in rice farming. The usage of seeds that are done proportionally with land area, and noticed the good quality would give good growth and high production. The result of observation and direct interview with farmers were known that the usage of seeds by respondents were very varies when seen by source, amount and term of seeds quality that used.

Rice seeds that often used were Cisantana seeds. Cisantana seeds were seeds that produced by cultivator farmers, which taken from their products. The number usage of rice seeds by farmers were varies respondent (Table 1).

Table 1. The usage average of seeds against rice production

\begin{tabular}{ccc}
\hline Numberof seeds $(\mathrm{kg})$ & \multicolumn{2}{c}{ Average ofrice production $(\mathrm{kg})$} \\
\cline { 2 - 3 } & Seeding direct system & Seeding indirect system \\
\hline 15 & $2,186.67$ & $1,445.11$ \\
20 & - & $1,446.89$ \\
25 & $1,149.24$ & $1,788.44$ \\
30 & $1,050.24$ & $1,800.42$ \\
35 & $1,655.51$ & $1,952.52$ \\
40 & $2,261.61$ & $1,523.84$ \\
50 & $1,831.68$ & $3,220.43$ \\
$>50$ & $2,888.51$ & - \\
\hline Average/ha & $1,826.28$ & $1,748.21$ \\
\hline
\end{tabular}

The usage average of rice seeds on seeding direct system amounted $51.82 \mathrm{~kg} /$ ha and usage average of rice seeds on seeding indirect system amounted $27.17 \mathrm{~kg} / \mathrm{ha}$. This difference was due to the seeding indirect system used seeding. On average, seeding direct system produced higher rice production, especially in the usage of seeds were more than $50 \mathrm{~kg} /$ ha (Ameen et al. 2014). The density of seeds which are high can be considered as a weed management strategy (Juraimi et al. 2013; Ikeda et al. 2008). Besides the density of seeds, seeds types also affect the rice growth on seeding direct system (Islam et al. 2014).

\subsubsection{The Usage of Fertilizers}

Fertilizers are one of production factors that can increase the fertility and improve the growth of crops so that can increase crops production. Types of fertilizers that were used by rice farmers of seeding direct system and seeding indirect system were Urea, ZA, KCl, SP-36, and PPC (liquid complement fertilizer). The usage of fertilizers by farmers based on land area are shown in Table 2.

Table 2. The usage average of fertilizers in rice farming

\begin{tabular}{cccccc}
\hline \multirow{2}{*}{ System } & \multicolumn{5}{c}{ The usage average of fertilizers } \\
\cline { 2 - 6 } & Urea (kg/ha) & ZA (kg/ha) & SP-36 (kg/ha) & $\mathrm{KCl}(\mathrm{kg} / \mathrm{ha})$ & PPC (1/ha) \\
\hline Seeding direct & 128.97 & 36.41 & 53.10 & 49.25 & 4.95 \\
Seeding indirect & 125.00 & 28.06 & 54.85 & 49.11 & 2.14 \\
\hline
\end{tabular}

The usage average of fertilizers for rice with system of seeding direct and seeding indirect were relatively same. The usage of Urea fertilizers were higher when compared to other types of fertilizers. Farming with seeding direct system, crops grew directly from seeds while with seeding indirect system, crops were from seeds that aged 21 days. Rice of seeding direct system were longer in rice land than rice of seeding indirect system, therefore Washio (1992) argued that rice fertilizers dosage of seeding direct system, especially N, should be 
$20-30 \%$ higher than rice fertilizers of seeding indirect system. The giving of $\mathrm{N}$ fertilizers were reduced in the half of first growth, but were increased in primordia stage and panicle establishment. According to Qi et al. (2012), the giving of $\mathrm{N}$ fertilizers have to be given on a regular basis, because it is related with the evaporation of ammonia that can inhibit the growth of rice crops.

\subsubsection{The Usage of Pesticides}

Pests attack and diseases are one of factors that can cause the decreasing of production level on a farming, so that pests attack and diseases need to be controlled by using pesticides (Singh et al. 2008; Mahajan et al. 2009). Types of pesticides that were often used by rice farmers with seeding direct system and seeding indirect system namely DMA, Dharmabas, Dursban, and Clipper. Types and quantities of pesticides that used by farmers were very dependent on land area and state of rice crops against pests and crops diseases (Table 3).

Table 3.The usage average of pesticides in rice farming

\begin{tabular}{lcccc}
\hline \multirow{2}{*}{ System } & \multicolumn{4}{c}{ The usage average of pesticides (1/ha) } \\
\cline { 2 - 5 } & DMA & Dharmabas & Dursban & Clipper \\
\hline Seeding direct & 0.88 & 1.37 & 0.56 & 0.35 \\
seeding indirect & 0.78 & 0.84 & 0.51 & 0.37 \\
\hline
\end{tabular}

The usage of pesticides by farmers have to notice the problem of environmental sustainability and apply wisely. Overspray can cause pollution on environment, especially on water and turn off non-target organisms. The usage of various technologies of weed control that support each other and integrated are highly recommended. The integrated approach are recommended for control of weed sustainable om seeding direct system, such as the usage of certified seeds, cultivation of land that is proper, irrigation water management, crops rotation, seeding density that is higher, as well as the proper usage of pesticides are technologies that compatible each other and synergistic to support the weed control effectively (Juraimi et al. 2013; Khaliq and Matloob, 2011; Akbar et al. 2011; Khaliq et al. 2013).

\subsubsection{The Usage of Labors}

Labors are one of production factors that support the success of farming. The usage of labors that are effective as well as have abilities and sufficient skills tend to increase the production of farming. The usage of labors are very dependent on the types of work that contain in each farming. The labors that used by farmers were labors from within the family and outside the family. Types of farming activities in rice farming with seeding direct system included land cultivation, cropping, weeding, fertilizing, control of pests and crops diseases, harvest, transporting crops and drying while rice farming with seeding indirect system included seeding, land cultivation, cropping, weeding, fertilizing, HPT control, harvest, transporting crops, and drying. The usage average of labors in rice farming with seeding direct system were $75.22 \mathrm{HH} /$ ha. The usage average of labors in rice farming with seeding indirect system were $83.74 \mathrm{HH} /$ ha. It showed the usage of labors in seeding indirect system were higher when compared with seeding direct system (Bhushan et al. 2007).

Seeding direct system can be adopted by farmers, especially in production areas of rice with rare and expensive labors. Sowing seeds in the array can use a tool that is called "atabela" (direct seeding tool). With this system, the outpouring of labors to plant rice only 1-2 persons / ha. If rice farming with seeding direct system is developed, then the reapers need to be available on the farmers level. If the reapers are not available, the costs of harvest will still be expensive so the efficiency of production costs are not achieved.

\subsection{Analysis of Rice Farming with System of Seeding Direct and Seeding Indirect}

Analysis of farming is a way to calculate the amount of income in a farming. Income of rice farmers with system of seeding direct and seeding indirect could be known by calculating the difference between total revenue and total cost.

The income average of rice farming with system of seeding direct and seeding indirect are shown on Table 4 . 
Table 4. Income of rice farming

\begin{tabular}{llr}
\hline No. Analysis & $\begin{array}{c}\text { Rice Farming with Seeding Direct } \\
\text { System / ha / season }\end{array}$ & $\begin{array}{c}\text { Rice Farming with Seeding Indirect } \\
\text { System / ha / season }\end{array}$ \\
\hline 1 Rice Production & $1,826.28$ & $1,748.22$ \\
(kg) & & $7,000.00$ \\
2 Rice Costs / kg (IDR) & $7,000.00$ & $12,237,540.00$ \\
3 Revenue (IDR) & $12,783,960.00$ & \\
4 Costs: & & $85,084.75$ \\
a. Fixed Costs & $79,627.91$ & $800,000.00$ \\
Shrinkage (IDR) & $800,000.00$ & $268,813.56$ \\
RentLand (IDR) & $288,953.49$ & $1,153,898.31$ \\
Others (IDR) & $1,168,581.40$ & \\
Sub Total a (IDR) & & $2,933,474.58$ \\
b.Variablecosts & $2,632,531.98$ & $107,796.61$ \\
Labors Costs (IDR) & $206,511.63$ & $512,457.63$ \\
SeedsCosts (IDR) & $572,988.37$ & $270,406.78$ \\
FertilizersCosts (IDR) & $312,593.02$ & $3,824,135.59$ \\
Pesticides Costs (IDR) & $3,724,625.00$ & $4,978,033.90$ \\
6 Sub Total b (IDR) & $4,893,206.40$ & $7,259,506.10$ \\
7 Total Costs(5 + 6) & $7,890,753.60$ & \\
8 Income (3 - 7) & & \\
\hline
\end{tabular}

The statistical analysis result of two independent samples $t$ test against income in rice farming with seeding direct system and rice farming with seeding indirect system showed the probability value $0.001<0.05$ at $95 \%$ confidence level of two-tail test. It showed rejecting the null hypothesis that meant there was a significant difference between income of rice farming with seeding direct system and rice farming with seeding indirect system.

Table 4 shows that income of rice farming with seeding direct system are higher when compared with income of rice farming with seeding indirect system. The difference of income in this research was caused by the difference of rice production on seeding direct system and seeding indirect system, where rice production on seeding direct system were higher than rice production on seeding indirect system. The difference in this production tended was caused by the usage of production factors that had different amount, such as seeds, fertilizers and pesticides. It is accordance with the opinion of Supriadi and Malian (1993), that the seeding direct system technique by using the cropping tool do not need seedbed such as in seeding indirect system technique. Seeds were soaked directly for 24 hours then dried for 12-14 hours and planted directly in the array. The seeds that were used around $51.82 \mathrm{~kg} /$ ha while seeding indirect system only $27.17 \mathrm{~kg} /$ ha. The number of different seed then the population number of rice would also be different so it tended increasing the production of rice per hectare. Likewise, the usage of fertilizers more tended increasing rice production. The usage of pesticides tended suppressing the production loss caused by pests attack and diseases in rice crops with seeding direct system.

The income difference was also caused by the total costs of rice production with seeding direct system were lower when compared to the costs of rice production with seeding indirect system. The difference of total costs was caused by variable costs of rice production with seeding indirect system were bigger, where in rice crops with seeding indirect system used more labors. It was accordance with the opinion of Adnyana (1996), that when compared between the usage of seeding indirect system with with seeding direct system, then seeding direct system would give some advantages, among others:

1. Labor costs outside harvest were lower 25-30 percent

2. Production facilities costs were lower 5-10 percent.

3. Results per hectare were 10-25 percent higher and the grain costs as well as rice were higher (due to better quality).

4. The net income of farmers increased from IDR 1.2-1.5 million / ha / season became IDR 2.0-2.5 million / ha / season.

The income difference showed that rice farmers in areas which are rare and expensive labors recommended for planting in rice with seeding direct system because more profitable if compared with seeding indirect system. 
Farming with seeding direct system then reapers need to be available on the farmers level. If the reapers are not available, the costs of harvest will still be expensive so the efficiency of production costs are not achieved.

\section{Conclusion}

Farming with seeding direct system could save labor when compared with farming with seeding indirect system. The income average of rice farming with seeding direct system were bigger than seeding indirect system. This difference was due to the rice production with seeding direct system were higher so that the total acceptance on seeding direct system were higher and total costs on seeding direct system were lower if compared with seeding indirect system. Rice farming with seeding direct system had a prospect to be developed in irrigated land with rare and expensive labor. However, the application of this system needed to be balanced with the usage of fertilizers, herbicides and reapers so the labor efficiency could occur.

\section{Acknowledgements}

The author would like to thank Prof. Dr. Ir. Muhammad Basir, SE., MS. and Prof. Dr. Ir. Made Antara, MP., who had guided and directed the author. The author also liked to thank the reviewers so this paper could be published.

\section{References}

Adnyana, M.O.(1996).ProspekdanKendalaPengembanganTehnikTanam Benih Langsung (Tabela) dalam SUTPA, dalam Made Oka Adnyana dkk (eds) monographSeriesNo. 19: PengkajianSUTPA: Konsep, Keragaan Empiris dan Prospek.

Akbar, N.,Ehsanullah, Jabran, K., \&Ali, M. A. (2011). Weed management improves yield and quality of direct seeded rice.Australian Journal of Crop Science,5(6), 688 - 694.

Ameen, A.,Aslam, Z.,Uz Zaman,Q.,Ehsanullah,Zamir, S. I., Khan, I., \&Subhani, M.J. (2014). Performance of Different Cultivars in Direct Seeded Rice (Oryza sativa L.) with Various Seeding Densities. American Journal of Plant Sciences, 5, 3119-3128. http://dx.doi.org/10.4236/ajps.2014.521328

Bhushan, L., Ladha,Jagdish, K.,Gupta, Raj, K.,Singh, S.,Tirol-Padre, A.,. Saharawat, Y. S, Gathala, M., \&Pathak, H. (2007). Saving of Water and Labor in a Rice-Wheat System with No-Tillage and Direct Seeding Technologies.Agronomy Journal, 99(5), 1288 - 1296.

De Datta, S.K., \& Flinn, J.C. (1986). Technology and economics of weed control in broadcast seeded flooded tropical rice. Asian Pacific Weed Science Society Conference, 10, 51-74.

Ikeda, H., Kamoshita, A., Yamagishi, J., Ouk, M., \& Lor, B. (2008). Assessment of management of direct seeded rice production under different water conditions in Cambodia. Paddy Water Environ, 6, 91 - 103. http://dx.doi.org/10.1007/s10333-007-0103-9.

Islam, M. K., Islam, Md. S., Biswa, J. K., Lee, Si. Y., Alam, I., \& Huh, M. R. (2014). Screening of rice varieties for direct seeding method.Australian Journal of Crop Science, 8(4), 536 - 542.

Juraimi, A. S., Uddin, Md. K., Anwar, Md. P., Mohamed, M. T. M., Ismail, M. R., \& Man, A. (2013). Sustainable weed management in direct seeded rice culture: A review. Australian Journal of Crop Science, 7(7), 989-1002.

Khaliq, A., \& Matloob, A. (2011). Weed-crop competition period in three fine rice Cultivars under direct-seeded rice culture. Pak. J. Weed Sci. Res., 17(3), 229 - 243.

Khaliq, A., Matloob, A., Ihsan, M. Z., Abbas, R. N., Aslam, Z., \& Rasool, F. (2013). Supplementing Herbicides with Manual Weeding Improves Weed Control Efficiency, Growth and Yield of Direct Seeded Rice.International Journal of Agriculture and Biology, 15(2), 191 - 199.

Mahajan, G., Chauhan, B.S., \& Johnson, D.E. (2009). Weed management in aerobic rice in Northwestern Indo-Gangetic Plains. Journal of Crop Improvement, 23, 366-382.

Qi, X, Wu, W., Peng, S., Shah, F., Huang, J., Cui, K., Liu, H., \&Nie, L. (2012). Improvement of early seedling growth of dry direct-seeded rice by urease inhibitors application. Australian Journal of Crop Science, 6(3), $525-531$. 
Rao, A.N., Jhonson, D.E., Sivaprasad, B., Ladha, J.K., \& Mortimer, A.M. (2007). Weed management in direct seeded rice. Advances in Agronomy, 93, 153 - 255.

Singh, S., Ladha, J.K., Gupta, R.K., Bushan, L., \& Rao, A.N. (2008). Weed management in aerobic rice systems under varying establishment methods. Crop Protection, 27, 660 - 671.

Soekartawi(2003).Teori Ekonomi Produksi. PT. Raja Grafindo Persada. Jakarta.

Supriadi, H., \& Malian, A.H. (1993). Kelayakan Agronomis Tekhnologi Budidaya SebarLangsungdiLahanSawahIrigasi.Dalam Muhyidin Syamdkk (eds),ProsidingSimposiumIII ;KinerjaPenelitianTanamanPangan. Buku 3, Puslitbang Tanaman Pangan Bogor.

Washio, O. (1992). Direct seeding rice culture in Japan: Its technical outlook. Farming Japan, 26(1), 11-19.

\section{Copyrights}

Copyright for this article is retained by the author(s), with first publication rights granted to the journal.

This is an open-access article distributed under the terms and conditions of the Creative Commons Attribution license (http://creativecommons.org/licenses/by/3.0/). 